\title{
Political Reforms for Prosperity and Political Resistance in Botswana
}

\author{
Zibani Maundeni ${ }^{1}$, Bontle Masilo ${ }^{2} \&$ Patience Petros ${ }^{3}$ \\ ${ }^{1}$ Professor of political science, University of Botswana \\ 2. A PhD student at the University of Sussex in the United Kingdom \\ ${ }^{3}$. A Master's student at Wuhan University, China \\ Correspondence: Zibani Maundeni, Professor of political science, University of Botswana.
}

Received: November 15, 2017

Accepted: December 21, 2017 Online Published: December 28, 2017

doi:10.20849/ajsss.v2i4.268

URL: https://doi.org/10.20849/ajsss.v2i4.268

\begin{abstract}
A people thought to be passive, weak and docile surprised many when they revolted against encroaching authoritarianism in their country - Botswana. What started under Ian Khama as the most feared and potentially productive regime turned out to be the most opposed and most beleaguered. How did this reverse happen? Many authors (including Good, Taylor and others) mistakenly assumed that Botswana's civil society was too weak and fearful, and that it would not stand up to any dictatorship. In contrast, Botswana towards the end of 2011 had reached a point at which civil society constantly challenged and clashed with government, resisting growing authoritarian tendencies. The political scenario of mid 2011 characterised by a long drawn public service strike was the clearest signal that the president was no longer feared. This paper focuses on Khama's political reforms and the political resistance that accompanied them. It argues that Ian Khama introduced several reforms that met lots of resistance that threatened the stability and sustainability of the Botswana society. The paper concludes that political reforms have left the Botswana society deeply divided, but alert.
\end{abstract}

Keywords: political reforms, cultural distortion, ideological shifts, political resistance, public-sector strike

\section{Introduction}

President Ian Khama's assumption of office in 2008 was characterised by the announcement of numerous Ds (democracy, dignity, discipline and delivery in no order), and followed by tough new policies on alcohol consumption, heavy traffic fines, a re-structured and heavily financed intelligence community, the Media Act and others. Discipline and delivery, and fighting corruption, appeared to be President Khama's top priorities and the regime promised to be the most productive of all. While these Ds are neutral developmental values, their authoritarian implementation changed their outlook, compelling them to promote non-democratic and un peaceful politics. Yet as 2016 came to a close, it was still being reported that services had slowed down, delivery was poor, and corruption was high. A newspaper article appearing on the $22^{\text {nd }}-28^{\text {th }}$ September 2013 issue of Sunday Standard was headlined: 'civil servants sabotaging gov't service delivery projects'. It covered the slowdown of border crossing despite a P250million computerization of Botswana passports, slow transaction speed despite a P63million Accounting and Budgeting system (GABS) introduced in 2007 by the Ministry of Finance and Development Planning (MFDP). The newspaper report made the following observation: 'Botswana Government's multi-million pula investments in information technology infrastructure is failing to speed up the sluggish service delivery in the public service because officers are sleeping on the job, the 2013 Public Survey Customer and Employee Satisfaction survey financed by UNDP has revealed' ( $p$ 6). The sabotage mentioned above and the reaction of the state to it should be understood in the context of the country's politics of resistance that was emerging. Our argument is that the rapid changes that accompanied Khama's early presidency bordered on chaos which generated resistance from the civil service, civil society, private media and opposition political parties.

\subsection{Reforms Fuelling Resistance}

What characterised the reforms of the Khama regime and later boiled into anger and into resistance was the manner in which senior civil servants (about 19 in a space of 6 months) were expelled, in which senior ruling party officers (including ruling party MPs) continued to be expelled after the 2009 general elections, in which senior army officers were being retired, in which academics and priests who had lost favour with the regime were being declared persona non-grata (Ditlhase, 2013). Gomolemo Motswaledi, a senior ruling party 
functionary who had taken President Khama to court over sharp differences over the administration of the party (Tautona Times, 2009; Sunday Standard 2009), was suspended and his candidature recalled in a manner that bordered on inhumanity. His political career within the BDP was sabotaged more so. All that were retired or expelled after him bore the same stamp. These joined forces with the striking workers to confront the Khama regime, spearheading a public service strike never seen in Botswana's entire history, and the near collapse of service delivery that followed. Above all, the mounting extra-judiciary killings that followed Khama's ascendancy into office were the most visible reminder of the brutality of the new regime. Clifford Geertz warns about the dangers of sudden changes that amount to chaos:

There are at least three points where chaos - a tumult of events which lack not just interpretations but interpretability - threatens to break in upon man: at the limits of his analytic capacities, at the limits of his power of endurance, and at the limits of his moral insight. Bafflement, suffering, and a sense of intractable ethical paradox are all, if they become intense enough or are sustained long enough, radical challenges to the proposition that life is comprehensible and that we can, by taking thought, orient ourselves effectively within it challenges with which any religion, however 'primitive', which hopes to persist must attempt somehow to cope' (Geertz, 1973: p100).

This means that, the Khama regime's promotion of tough actions in many fronts characterized a sudden eruption of events that resulted in state-induced chaos. The multi-layered suffering due to the forced retirement, the extra-judiciary killings and the strikes (that almost crippled public service delivery) imposed on the nation, challenged society's analytic capabilities, its power of endurance and dampened its moral insight. President Khama's refusal (during the 2011 strike) to meet former presidents, to meet organized priests, to meet BDP back benchers, to meet opposition leaders (Makgapha 2014, BCP press release June 2011; Bodilenyane 2012; Sebudubudu and Botlhomilwe 2011) and unions, and his refusal to offer a reasonable salary package and to reinstate dismissed workers and to re-consider the no-work-no-pay rule, prolonged the strike that produced enormous human suffering.

The introduction of tough state action and strict state control in many fronts initially instilled fear (rather than discipline and productivity as desired by the presidency) in the whole public service, in the members of the rival faction within the ruling party, in the private media, in religious circles, in academics and in civil society. Khama's regime placed great emphasis on discipline as confirmed by the rushed introduction of strict liquor trade regulations to curb perceived alcohol abuse, a rather elaborate dress code for public servants barring them from wearing anything that could bring the integrity of public service in disrepute.

During the period of the strike (2011), the fear of telephone tapping even spread to ruling party MPs of the rival faction and to other peoples that sympathised with workers (Mogalakwe, 2013; Mmegi ,04 February 2010 ). Although the then Minister of Defence, Justice and Security (Ramadeluka Seretse) denied allegations of phone tapping and spying, the perceptions persisted. These developments existed parallel to, and outside the Tswana value systems of mmualebe, and threatened the society's cognitive resources. It was becoming clear to all that a new dispensation based on discipline was being created and that free speech and dialogue were under threat.

\subsubsection{Reforms in Conflict with Culture}

In contrast, Botswana citizens are traditionally accustomed to being consulted and allowed to debate even things they did not understand, where even the most irrelevant and the most uninformed, were given repeated chances to speak (mmualebe gore mmualentle a ntshe la gagwe). Batswana believe that bad ideas that were publicly aired created room for good ideas to emerge. Consultation, even if it did not result in the adoption of suggested ideas or their incorporation into policy decision gave Batswana a sense of involvement and illusion of participation and engagement. Batswana believe that restricted debate and government impositions prevented good ideas from emerging and from gaining popularity. Thus, Tswana social values were against impositions of any sort and promoted the diversity of opinions. Dialogue was a central feature of the historical Tswana society. But dialogue was threatened, paralyzing the moral insight of the society. All this contributed to the fear and anger that was brewing against the Khama regime.

\subsubsection{Scholars Misunderstood the People}

Scholars such as Good (2009) and Taylor (Good was declared a prohibited immigrant) started writing about the rising authoritarianism, and others such as Sebudubudu and company, started writing about its entrenchment. They portrayed the Khama regime as imposing militaristic discipline in the society, intolerant to independent thought no matter how less challenging, brutal in its dealings with perceived opponents, and immoral in not seeing the human suffering that accompanied the strike. However, it seems that all these authors got it partly right and partly wrong: they got it right in the actions of the Khama regime, but they got it wrong in not seeing 
the rising tide of resistance against Khama's authoritarian tendencies While there was no doubt that the Khama regime was inclined towards authoritarianism, the forces of resistance were equally gathering pace to match it. Thus, the above authors' only saw the rising authoritarianism, and failed to see the rising forces of resistance that paralleled it.

\subsubsection{Ideological Shifts within the Ruling Party and Government}

Khama's reforms also threated the BDP's ideology of development. Historically, the ruling Botswana Democratic Party (BDP) was known as the pragmatic party of development (characterised by focusing and achieving economic growth, attracting foreign investment, expanding infrastructure, promoting equitable quality education and health, securing private property rights, and so on). Scholars who wrote about Botswana of the 1960 s up to the 2000s, characterised the BDP led government as an administrative state (Charlton, 1991) (in which expertise was valued, attracted and appropriately deployed to plan and execute development plans) and used resources prudently, as a developmental state (Leftwich, 1996; Maundeni, 2002; Taylor, 2003) (in which state power was centralised in the Ministry of Finance and Development Planning (MFDP) that was headed by developmentally-oriented vice presidents who mobilised all other governmental institutions and the rest of society to prioritise capitalist developmental goals, (Maundeni, 2002; Taylor, 2003; Sebudubudu, 2005) marginalised welfarist elements who grouped themselves predominantly in the Botswana National Front (BNF). With an economic growth agenda and a catching up attitude with the rest of Africa, the early BDP led government (of Seretse Khama, Quett Masire and Festus Mogae) centralised the ownership of natural resources in the hands of central government expatriate administrators who designed its development plans and executed them, who designed strict labour laws that restricted the growth of the labour movement and moderated its activities, who forged partnerships with the best in the corporate world such as De Beers to establish functional and technological advanced mining, and who designed the education system, linking it to the nurturing of expertise for the public service (Jefferis 1998; Masire 2006; Maundeni, 2002).

In contrast, our assessment of Botswana in 2016 and 2017 makes three contrasting observations. The first two are positive. The first is to the effect that even under Ian Khama, Botswana was still considered a success story. International assessments such as that of the Freedom House (an international NGO) from the United States see Botswana as a success story in terms of political rights and civil liberties. In its 2013/2014 country overview report covering 195 countries, Freedom House classifies Botswana among the 90 free countries, as compared to 58 others classified as partly free, and 47 others as not free. In that report, Botswana is among 11 free countries in sub-Saharan Africa, with high scores for both political and civil rights.

In a parallel international assessment called an index of democracy that covers 196 countries, the Economist Intelligence Unit (EIU) rates Botswana well. Using categories such as 'full democracies', 'flawed democracies', 'hybrid regimes', and 'authoritarian regimes', 'Botswana's score improved from 7.3 in 2010 to 7.85 in 2012. Consequently, its ranking also improved from 30 in 2010 to 35 in 2012" (EIU, 2012). In addition, the Ibrahim index of African governance, considered one of the most inclusive grading of African governance, uses categories such as safety and security, rule of law, transparency and corruption, participation and human rights, sustainable economic opportunity, and human development, ranked Botswana as the third best, same as in 2010 and 2011. Thus, Botswana is still classified among the top performers in several fronts.

Our second observation is that Botswana under President Khama has also done well under recession conditions. On the one hand, the global financial and economic crisis of 2008-9 hit Botswana too, with global diamonds sales sharply falling and diamond mines in the country closing down. The World Bank (2015) observed that the temporary closure of diamond mines in the first half of 2009 caused the economy to fall into recession, with GDP growth rates of -7.8 per cent in 2009 as a whole, including a budget deficit and balance of payments deficits. On the other hand, the non-mining sector of the Botswana economy grew steadily, at 9.7 per cent and 7.5 per cent in 2011 and 2012, respectively. The Botswana economy recovered strongly by 2010, with mining making significant contributions, even though fluctuations in growth rates followed in the subsequent years, the economy was stable, fuelling demands for salary increases from the trade unions as shall be shown below.

Our third observation is a negative one, being that the BDP led government of Ian Khama has shifted focus from being an administrative state, and from being a developmental state. Instead, retired soldiers have assumed the presidency and the vice presidency, including senior management positions in government ministries and departments. While experienced local economists no longer become presidents or vice presidents, expatriates have either retired or are seen as security threats and are being driven out of the country. Instead, retired soldiers who have no economic background and who have no background in public administration and economic management took over government, including the presidency and vice presidency under Ian Khama's initial 
regime. Some scholars such as Good (2011) labels it militarisation and authoritarianism (Speculation is that Good was deported from the country partly because of this observation, and partly for pointing out that the Mogae-Khama regime was fraudulently displacing the Basarwa from the CKGR for diamonds and for tourism). While Botswana under Khama no longer had a developmentally oriented vice president, it did not have a developmentally oriented president either. Both President Ian Khama and Vice President Lt. Gen Mompati Merafhe were primarily security oriented, and placed the security institutions at the centre of state power at a time when the country and the world experienced an economic recession requiring strategic economic leadership. Under them, security issues dominated the local politics, and development orientation (The central place once enjoyed by technocrats in the ministry of Finance and Development Planning has since been taken over by military retirees with little experience in development) that the country needed most, was marginalised. Equally, the Ministry of Finance and Development Planning (MFDP) was no longer the flagship ministry that it was, having been reduced to a junior ministry headed by politically lightweights (people without even political positions in the ruling party). It no longer attracted vice presidents for its ministers. In addition, off-budget facilities were established, weakening the MFDP's control over government monies and empowering the presidency to spend as it wished.

Initially, BDP had proved to be one of the most stable political parties in Africa, handling its internal differences through constitutionalism and compromises (Maundeni and Lotshwao, 2011), enjoying smooth change of leadership, handling primary elections in an organised and respectful fashion, factors that created internal party stability and enhanced its ability to win elections. At that time, the Democracy Research Project (DRP) of the University of Botswana used to be hired to conduct BDP's central committee elections to safeguard the integrity of internal elections. A stable BDP government that was developmentally focused was also attractive and attracted political support from all walks of lives, aligned itself with ruling parties around Africa and promoted democracy and peace. State institutions worked in a harmonious and coordinated manner, without rivalling each other.

In contrast, the BDP under Ian Khama became securitised, and the security unconscious DRP no longer fitted into the BDP's scheme of things. In the build up to the 2014, there were speculations that BDP engaged Israeli security consultants, leading to perceptions of threatened personal security of citizens and to insecurity of foreign residents alike, and to the view that the party threatened the democracy of the country. These bad perceptions fuelled suspicions that the party aimed to rig elections (the BDP had allegedly set up a war office within the presidency in 2014), creating a risky situation that threatened the integrity of the 2014 election. Thus, the Khama regime securitised the politics of the ruling party, the institutions of the state and displaced the developmental orientation of the state with a security orientation that regarded all those outside the state system as security threats.

In addition, while the BDP lost its internal stability under President Masire, the situation worsened under Mogae (1998-2008) and under Khama (2008-to date). Sebudubudu and Botlhomilwe (2011) observe that factionalism has deepened under Khama's leadership leading to the party's split in 2010. When the BDP suffered rivalry between its A-team (a faction led by the then President Festus Mogae, Vice President Ian Khama and others) and its Barataphathi (led by former BDP Secretary General Daniel Kwelagobe and Ponatshego Kedikilwe) factions, when it suffered expulsions and finally split in 2010, when it lost Secretary Generals Gomolemo Motswaledi and Kentsi Rammidi), and chairman Guma Moyo in 2013 (He left BDP in 2010, and re-traced his steps back later to the BDP), it was evident to all that the party was no longer enjoying political stability. Under Ian Khama, the BDP suddenly abandoned the principles of compromise and tolerance that were once the instruments of conflict management in the party, and started championing suspensions and expulsions of those from the Barataphathi faction. Alleged nation-wide irregularities of its 2013 primary elections, fuelled by the party's failure to substantively fill the position of vice president (until that position was filled after the 2014 election), led to more internal instability as factions positioned themselves to fill that position.

\subsubsection{Failure to Deal with Corruption}

Corruption, and failure to be seen to be fighting it, has always been a challenge to the ruling BDP. Years ago (in the early 1990s) when the BDP government faced corruption scandals and the possibility of writing off huge debts of senior government politicians, Festus Mogae as Minister of MFDP rose to restore sanity into the BDP government, insisting that all persons (including the then President Masire) who owed the National Development Bank large sums of money, pay back just like those who owed private banks (Good, 1994). When it seemed as if the Masire presidency was stalling on the issue, NDB debts of senior government officials and politicians were leaked to the media that published the amounts each individual owed, as well as the arrears (Good 1994). While threats to sue media houses were made, all the senior politicians (including ministers and the then president) paid 
up, and BDP gained its credibility as a party ready to deal with corruption. The BDP government under Ian Khama was at it again, facing corruption scandals by senior officials in its government including the director of the intelligence agency- DIS, who has never been brought to the courts, Cabinet ministers ), and this time, the party and anti-corruption state institution were powerless to deal with it. The designated body was seemingly failing. Exacerbating the problem is that the BDP dominated parliament also struggles to hold the government accountable due to the leadership's tight control over its legislators. President Khama has both refused to suspend the implicated personalities and encouraged them to stay in office. Under such a setup, the anti-corruption agencies and the Parliament were seemingly failing to deal with corruption, factors that fuelled resistance against his regime.

\section{Political Resistance}

Ironically, opposition against the Khama dictatorship swelled within the BDP itself, particularly at the Kanye Congress that elected an overwhelmingly central committee from a rival faction of the party, with Khama as the only one from the other faction. It was that Central Committee that sought to check Khama's powers and started the ball rolling, questioning his perceived unilateralism and seeking legal opinions against him (Sunday Standard, 2009; Makgala and Giollabhui, 2014). It should be remembered that the initial revolt within the ruling party happened at a time when the private media and its organizations such as Media Institute of Southern Africa (MISA-Botswana) had already started their own campaign against the media Act of 2008, refusing to participate in its oversight structures set up by the government, and rendering the implementation of the law impossible (Segaetsho, 2009). The Botswana Law Society also boycotted the Media Appeals Committees established by the Act. The revolt within the BDP also happened at a time when the public sector unions that had started unionizing, called for the speedy implementation of the 2008 Public Service Act in order to stop the forced retirement which the government was speedily implementing against its employees.

\subsection{Resistance from the Public Sector Trade Unions}

The public service trade unions had also started to openly identify with the rival Barataphathi faction of the ruling party and with opposition parties, and became actively involved in the 2009 elections, including their issuance of posters of five men (including Vice President Merafhe) whom they accused of being a danger to democracy (Keorapetse, 2013). The entry of public sector trade unions into politics emboldened civil society organizations such as Botswana Council of Non-Governmental Organisations(BOCONGO) that had already opposed the creation of a larger intelligence organization, and started organizing breakfast talks and radio debates on the 'State of the Nation' address. A revolt was gaining momentum!

\subsubsection{Wide-Spread Resistance}

By the time the Khama regime won the 2009 general election, it was already facing serious ideological challenges. Its securitised vision of Botswana characterized by a militarized state in which retired and serving soldiers controlled all the institutions (such as the DIS, public hospitals, prisons, the Central Transport Organization (CTO), and others, a completely loyal citizenry whose private life was strictly controlled by the state and by traditional authorities, a public workforce that was highly intimidated, obedient and weary of protests and demonstrations, a religious community that practically praised the political leadership and participated in enforcing state-sponsored morality (not religious morality), was under serious questioning. President Khama, known for his hostile attitude towards the media, was nowhere to defend the ideological orientation of his regime. Observers such as Log Raditlhokwa (deceased) noted that President Khama was not sufficiently visible and did not come up with a philosophy for his vision. A vision anchored on discipline without a public philosophy to sweeten it and to make it legitimate, exposed its naked dictatorial tendencies which came to define it.

In contrast, the Khama regime chose toughness and worked closely with the security forces and with conservative traditionalists, appointing a traditional chief to head a commission meant to revive cultural values (the creation of new values was not on its agenda and the strengthening of religious values was marginalized). Frustrated by what he perceived as an erosion of strong cultural values and the weakening of the authority of Dikgosi (chiefs), and by the failure of the state to put in measures to revive culture, Kgosi (Chief) Kgafela in Kgatleng district introduced his own cultural restoration initiatives, characterised by the banning of some churches and the beating of priests he considered disloyal to the chief, the banning of shebeens (beer drinking spots) and the introduction of traditional rites (Maundeni, Mbongwe and Masilo, 2015). The Bangwato (to whom Ian Khama is the natural chief) also voluntarily reinstituted similar rites, though characterized by less toughness. Thus, just like so many failed African societies, the Botswana that President Khama championed was on the verge of re-traditionalising. Modernization - new values to match globalization, and religious calling to work, 
were being de-emphasised in the new Botswana through deportations of priests and through law reforms that sought to make it impossible to form new churches. It would appear that Chief Kgafela's initiatives were in support of President Khama's, but evidence suggest that his efforts were actually earlier signs of subtle resistance. His vociferous condemnation of the constitution as well as outright attack on government officials was clear indication that he detested the Khama administration. His initiatives ran parallel those of the state, undermining the law, undermining state authority and all these invited Khama's onslaught as evidenced by criticism from the administration, straining the relations between Bakgatla chieftainship and the government. Botswana was slowly becoming an ugly place to live in.

The emerging resistance movement initially operated in fragmented manners whereby some elements of civil society participated in different capacities in the 2009 election. Some sectors of civil society such as trade unions took an active part in that election, de-campaigning some members of the ruling party. In particular, the Botswana Manual Workers Union circulated posters, de-campaigning against some candidates from the ruling BDP, accusing them of being a threat to democracy (Keorapetse, 2013).

\subsubsection{The Public Sector Strike}

By 2011, public sector unions under BOFEPUSO (Botswana Federation of Public Sector Trade Unions, including teachers) went on a nationwide legal strike that nearly paralysed government service delivery. The public sector unions demanded 16 percent wage increase, a figure that was reasonably high to provoke a government refusal. When the government offered a conditional zero percent and then a 5 percent (Director of Public Management, 2011) and later an unconditional 3 percent, the stage was set for a coordinated strike accompanied by calls for the resignation of President Ian Khama. Several fruitless negotiations were held between the government and the unions. Initially, government schools were kept open even though no classes were taking place, allowing students to organise a parallel rebellion that threatened to become violent (Ntibinyane, 2011; Ganetsang, 2011). Junior and secondary school Students went on strike, leading to riots in several villages such as Thamaga, Ramotswa, Molepolole, Mochudi and in the mining town of Selibe Phikwe (Ntibinyane, 2011). As a result, the Minister of Education and Skills Development announced the closure of all government primary and secondary schools! This development had no parallel in the history of Botswana. The closure of private schools for one week also followed. Meanwhile, hospitals and clinics went without a lot of their nurses and doctors and manual workers, turning patients away and risking lives. Matters got out of hand when some few nurses and doctors received letters of dismissal, prompting those on duty to join the strike and to bring more paralysis to the public sector institutions. There was no doubt that the strike was transforming into protest and slowly into resistance. This new frontier was a clear indication that President Khama would be resisted.

\subsubsection{Khama's Disdain for Dialogue}

President Khama's disdain for dialogue fuelled the protests. His refusal to meet with, the union leaders, opposition leaders, former presidents and priests, singled him out as the threat to the country's democracy. His visitation of distant rural areas where he told them that government had no money and that his government was not going to make any salary adjustments to people, who lived well, fuelled the protests. Towards the end of May 2011, President Khama presented a speech to the High Level Consultative Forum (where he met business leaders) where he categorically stated that government debt was too huge at 7 billion Pula, that he had no intention of worsening it by a further 2 billion Pula which is what the 16 percent wage demand amounted to. His position effectively meant that Botswana could most certainly burn and President Khama and his government was not going to help put out the fires. The government's dismissal of striking workers it classified as essential services, added impetus to the protests. Dismissals prompted most of their essential services colleagues to also join the strike in solidarity.

State politics that either closed all government schools in the whole country in anticipation of possible violence that could come with student joining already existing protests, or their opening without offering any teaching as the teachers continued the strike, state's insistence on firing those workers singled out as essential service staff, generated public outcry. However, tight control of information flow and manipulation of the state media denied the workers wide public sympathy (Ndlovu, 2011) that could have been a 'force multiplier' ensuring civil servants remain committed to their course. Intimidation of the striking workers by security agencies (Motshegwa and Tshukudu, 2012) further weakened the strike. However, judging by the protracted nature of the strike and the resilience displayed by the workers (never witnessed in the history of labour relations in Botswana) it would not be farfetched to conclude that the workers were determined to undermine the regime and to plunge public service delivery into crises. 


\subsubsection{A Cohering Resistance Movement}

After the first month of the strike, the emerging resistance movement started working with the opposition parties and made some political demands. Isolated voices within the resistance movement started calling for President Khama's resignation (Ntibinyane, 2011, Dipholo, 2011), failing which, they encouraged Parliament to pass a Vote of No Confidence or to remove him. Others called for a violent confrontation. Yet others called on the unions to end the strike in the interest of the greater society that was suffering immensely. This call came from the recognition that the Khama presidency's determination to prevail was so great that it would rather see the nation destroyed than give in to the unions. Other voices from the private media and the general civil society called for further negotiations even though these have broken down several times. Finally, the Speaker of Parliament called a General Assembly of Members of parliament, a term that had never been used before (Ntuane, 2011). The General Assembly of the members of parliament called on both parties to reach a compromise in order to end the national crisis brought about by the strike.

The desire to challenge authoritarianism galvanized the resistance movement which started calling for constitutional reforms, and for regime change! The emerging resistance movement for democratic restoration, economic revival, and clean governance with civilian humanism, started with civil society resisting both the formation of the expanded DIS and the new media regulatory structures of 2008. It gained momentum with the Barataphati faction sweeping the BDP's central committee election at the Kanye congress in 2009, and with Secretary General Gomolemo Motswaledi taking President Khama to court that ended with the former's recall (Lotshwao, 2011). The resistance movement gained ground with the expulsions and resignations of Motswaledi's supporters that led to the split of the BDP in 2010, with the public servants strike that ended with calls for regime change in 2011, with the all-inclusive negotiations among opposition parties that ended with the formation of the Umbrella for Democratic Change (UDC). The release of Margret Nasha's (then the Speaker of the Botswana Parliament) book 'Madam Speaker Sir' resulted in a major fall-out with Khama. The allegations on the possible existence of a hit list of opposition candidates facing assassination during the political campaign added its weight to the resistance movement (Kologwe, 2014). A public media blackout on Motswaledi's hugely attended funeral in Serowe, attended by former Presidents Masire and Mogae who openly criticized the Khama regime of intolerance and of diverging away from the rule of law that Botswana was known for (Pheko, 2014; Kavahemutui, 2014), added to the resistance movement. In what could be interpreted as a call for change of government, former President Masire said: "revolution happens when people lose confidence in government. If you are a ruling party you should know that you might one day be in opposition, and if you are in opposition you should know that you are a government in waiting," (Pheko, 2014 para.4). The release of Richard Khumoekae's The Scandalous Murdering of Democracy, a book critical of Khama's regime, also galvanized anti-Khama forces. All these culminated into a showdown in the October 2014 general election.

The self-declared forces of the restoration of democratic rule and good governance, stood against the BDP with a strong security orientation, and against the opposition $\mathrm{BCP}$ that was portrayed as betraying the resistance struggle by not joining the opposition coalition. In some strong sense, the 2014 election was not an ordinary election. The forces of resistance (civil society, public sector unions, private media, social media, and opposition political parties) unleashed revolutionary energy, aimed at sweeping away BDP rule under Khama. True to Skocpol (1979)'s 'states and social revolutions' that tied revolutionary success to international support and to defections in the military, the revolutionary coalition was able to attract international sympathy and support, and managed to divide the military. With a tainted international image, coupled with strained relations with neighbours and other African states as a result of Khama's foreign policy in the region characterized by his stand off against Mugabe's heavy-handed electioneering in Zimbabwe in 2008 (Zaba, 2014), Botswana was in danger of a serious political dilemma. Khama's government threat to arrest President Al Bashir of Sudan in case he visited Botswana (Dube, 2015), his seemingly deliberate absence from AU summits of heads of states, his uncharacteristic support for the International Criminal Court-ICC, was unsettling to say the least and was opposed by most ruling parties in the region and in Africa. His government's public sparring with the American Government over comments concerning the arrest of a newspaper editor over a story alleging that President Khama was involved in a car accident at night while driving himself, gave domestic forces immense momentum.

\subsubsection{Revolutionary Energy}

Revolutionary energy that expressed itself through the UDC and equally through the public sector trade unions, and through the private media and social media (particularly Facebook), mounted a spirited campaign that took President Khama by surprise and Botswana by storm. Hugely organized group-launches were organized for UDC candidates with glamorous tents, presidential buses, and with privately chartered helicopters to transport the UDC leader in order to help him look presidential, were deployed. A private radio station, Gabz FM (with 
support from trade unions and from the American and British embassies) organized constituency radio debates and presidential radio debates were aired nationally in a private radio station, revolutionizing Botswana's electoral democracy. While opposition candidates actively participated in the debates, the BDP boycotted them (Dingake, 2014).

Realizing that revolutionary wind was sweeping strongly, threatening his already destabilized BDP, President Khama abandoned his earlier position of keeping a low profile, personally re-launched all BDP parliamentary and council candidates across the country and made second and third visits to many constituencies and wards. In short, President Khama mounted a counter-resistance campaign spiced with threats of war should his party lose, talks of him going to prison should the opposition win, the hiring of Israeli consultants for unspecified clandestine works, the use of army helicopters to visit several constituencies a number of times, targeted verbal attacks on certain UDC candidates, the use of threatening telephone calls by unknown callers.

Unbeknown to Khama, an organized faction within the ruling party engineered (through rigging and other means) the loss in the party primary of his cronies (particularly those with military background to prevent them from being considered for position of vice president). To further limit Khama's influence on voting decisions in parliament, they fast tracked the amendment of parliamentary rules to require secret voting in Parliament for the Speaker, Deputy Speaker and Vice President (Daily News, 2014). In a sense, President Khama was facing spirited pressures from several fronts: from a broad-based opposition coalition enjoying regional and international support (including from ruling parties in the region), from the private media, from social media, and a revolt from an organized BDP faction that sought to frustrate his succession plan. But at the end of it all, the counter-revolution was partly successful and President Khama was re-elected to start his second term as president in October 2014. While President Khama's ruling party survived with 46.5 per cent of the popular voter and won the elections (BDP had 46.5, UDC 30.0 per cent and BCP 20.4 per cent) and a number of ministers) the opposition BCP was swept (winning only 3 seats out of 57) away by the democratic resistance current and by the counter-resistance state campaign.

\section{Conclusion}

President Khama thought reforms were necessary to launch Botswana into a developed society status characterised by a high income economy. He initiated widespread reforms regarding - the re-organisation of the ruling party aimed at instilling discipline and loyalty, improving the work ethic in the public service by sucking those considered as under -performing executives and deliberately weakening the bargaining council in order to reduce militancy in the labour unions, compelling the private media to promote fair reporting by instituting stringent regulations, and launching cultural revival in the society. The perceived or actual centrality of directorate of intelligence - DIS - in the state-initiated reforms instilled fear and anger into the population.

The reforms generated enormous resistance from Botswana's supposedly passive people. A strong reformist state was met with an initially fragmented and fearful resistance that gradually became fearless, militant and crystalized into the opposition coalition of the UDC that called for regime change. What was generally assumed to be a fearful and timid society re-organised into a resistance movement that left Botswana on the point of regime change and threatened a democratically elected government. We learn from this experience that state-initiated 'reforms from above', partly constitute authoritarianism that can easily incite resistance from the organised sectors of society, even from within the ruling party itself.

\section{References}

As I see it. (15 December, 2014). Mmegi Newspaper. Retrieved from http://www.mmegi.bw/index.

Bondanella, M., \& Musa, M. (1979). The Portable Machiavelli. Middlesex: Penguin Books.

Charlton, R. (2008). Bureaucrats and Politicians in Botswana's policy-making process: A Re-interpretation. Journal of Commonwealth and Comparative Politics, 29(3), 265-282. https://doi.org/10.1080/14662049108447615

Dingake, M. (July 15, 2014) Lighting Nevr Strikes Twice, Mmegi Newspaper. Retrieved from http://www.mmegi.bw/index.php?aid=44597

Ditlhase, Y. (2013 August, 13). Wolves in Sheep Skin, The Midweek Sun. Retrieved from www.themidweeksun.co.bw/news.html

Dube, M. (2014 August, 27). Doubts over cause of Botswana Opposition Leader's Death. African Review. Retrieved at http://www.africareview.com/News 
Dube, M. (2015 February 18). Botswana Ian Khama's love affair with the West. African Review. Retrieved From http://www.africareview.com/News

Economic Intelligence Unit. (2012). Index of Democracy.

Ganetsang, G. (2011 May 19). How public sector strike morphed into fight for regime change. Sunday Standard. Retrieved from www.sundaystandard.info/article.php

Geertz, C. (1973). The Interpretation of Cultures: Selected Essays. New York: Basic Books.

GooD, K. (2011). The Capacities of the People versus a Predominant, Militarist, Ethno-nationalist Elite: Democratisation in South Africa. Interface, 3(2), 311-358.

Good , K. (2009). The Presidency of General Ian Khama: The Militarization of the Botswana 'Miracle'. African Affairs, 109(435), 315-324. https://doi.org/10.1093/afraf/adp086

Good, K. (1994). Corruption and Mismanagement in Botswana. The Journal of African Studies, A Best Case Example, 32(3), 449-521.

Jacobs, A.J. (2010). Max Weber was right about the pre-conditions, just wrong about Japan: the ethic and its spirit of capitalism. The Open Area Studies Journal, 3, 12-29. https://doi.org/10.2174/1874914301003010012

Jefferis, K. (1998). Botswana and diamond-dependent development. In W.A Edge and M.H Lekorwe (eds) Botswana: Politics and Society, Pretoria, J.L van Schaik.

Jefferis, \& Nemaorani. (2015).

Kavahemutui, J. (2014 August 26). Nasha,Mogae, Masire , the growing list of disgruntled BDP elders. Botswana Guardian. Retrieved From http://www.botswanaguardian.co.bw/news

Keorapetse, D.L. (2013). Monopoly Politikos' An account of a De Facto One Party State and Lack of Regime Change in Botswana. In Amutabi, M.N \& Nasong'o, S.W (eds), Regime Change and Succession Politics, Retrieved From https://books.google.co.bw

Khama suspends party Secretary General. (2009 August18). Sunday Standard. Retrieved from www.sundaystandard.info/article.php

Kologwe, O. (2014, May, 16). Khama dispels assassination reports on his rivals, Sunday Standard.

Leftwich, A. (1996). Two cheers for democracy? Democracy and the developmental state. In A. Leftwich (ed) Democracy and Development (P. 279-295). Cambridge: Cambridge University Press.

Lotshwao, K. (2011). The Weakness of Opposition Parties in Botswana: A justification for more internal party democracy in the Dominant Botswana Democratic Party (BDP). African Journal of Political Science \& International Relations, 5(2), 103-11

Makgala J. \& Giollabhui. (2014). Botswana' Presidential Ambitious Party Factions and the Durability of a Dominant Party. In R. Doorensplect and Nijzink L . Party Systems, Palgrave Macmilllan. Retrieved From https://books.google.co.bw/books

Makgapha, S. (2014, February, 13). Saleshando, Modubule accuse Khama of political intolerance. Sunday Standard. Retrieved From www.sundaystandard.info/article.php

Masire, Q.K.J. (2006). Very Brave or Very Foolish? Memoirs of an African Democrat. Gaborone: Macmillan Botswana Publishing Co (Pty) Ltd.

Maundeni, Z. (2001). State culture and development in Botswana and Zimbabwe. Journal of Modern African Studies, 40(1), 105-132.

Maundeni, Z., \& Lotshwao, K. (2012). Internal organisation of political parties in Botswana. Global Journal of Human and Social Science, XII(1), 55-63.

Mdlalani, A. C. (2010 December 20). 2010 in review an exciting year that had everything for everybody. Sunday Standard. Retrieved from www.sundaystandard.info/article.php

Mogalakwe, M. (2013). Deconstructing National Security: The Case of Botswana. Sacha Journal of Policy and Strategic Studies, 3(1), 12-27.

Motshegwa B., \& Tshukudu T. T. (2012). Deep Rooted Conflicts \& Industrial Relations Interface in Botswana, Journal of Public Administration and Governance, 2 (3), 188-133 https://doi.org/10.5296/jpag.v2i3.2349 
Ndlovu, T. (2011 June 03). News Blackout on a Civil Service Strike. Sunday Standard. Retrieved from www.sundaystandard.info/article.php

Ntibinyane , N. (2014 August 29). BDP pays millions to Israeli company. Mmegi Newspaper. Retrieved from http://www.mmegi.bw/index.php?aid=44597

Ntibinyane, N. (2011 May 20). Tension Mounts over Escalating Botswana Protests. The Mail and Guardian. Retrieved from http://mg.co.za/article

Ntuane, B. (2011 June, 20). Statement by the Parliamentary Opposition Collective of the BMD, BCP,BNF on meeting President Khama. Sunday Standard. Retrieved From www.sundaystandard.info/article.php?

Parliament amends Standing Orders. (2014, Aug 07). Botswana Daily News. Retrieved From ww.dailynews.gov.bw/mobile/news-details.php

Pheage, T. (2015 February 02). Khama summon Dikgosi and pastors. Weekend post. Retrived From www.weekendpost.co.bw

Pheage, T. (2015 January, 19). Fire' churches body petitions Gov't. Weekend Post. Retrieved from www.weekendpost.co.bw

Pheko, I. (2014 August 14). Ndaba Puts on Iron Mask. The Midweek Sun. retrieved from www.themidweeksun.co.bw/news.html

Poteete, A. R. (October 20). Africa Plus essay - "Democracy Derailed? Botswana's Fading Halo, African Plus

Press Release Botswana Congress Party. (8 June, 2011) BCP Hold Khama Responsible for the Current Public Sector Strike.

Press Release. (14 April 2011). Director of Public Service Management, Status Regarding Salary Negotiations on Public Service Salaries for the Year 2011/2012 Between DPSM and Five Public Service Trade Unions. Retrieved From www.gov.bw/Global/DPSM/press.pdf?epslanguage=en

Ramadubu , D. (2014 February, 12). Khama calls emergency cabinet meeting. Botswana Guardian. Retrieved from http://www.botswanaguardian.co.bw/news

Sebudubudu, D. \& Botlhomilwe, Z,B. (2011). The Critical role of leadership in Botswana's development: What Lessons? Leadership, 8(1), 29-45. https://doi.org/10.1177/1742715011426962

Segaetsho, L. (2009 August 04). We applaud Law Society of Botswana on Media Practitioners Act. Mmegi Newspaper. Retrieved from http://www.mmegi.bw/index.php?aid=44597

Selemogwe, D. (2014 August 04). Was Motswaledi Killed. Botswana Guardian. Retrieved from http://www.botswanaguardian.co.bw/news/971-was-motswaledi-killed.html

Sepora, T. (2011 May 20). Teachers on strike, Students on the kill. The Voice Newspaper. Retrieved from http://www.thevoicebw.com/2011/05/20/teachers-on-strike-students-on-the-kill/

Skocpol, T. (1979). States and Social Revolutions: A Comparative Analysis of, France, Russia and China. Cambridge: Cambridge University Press. https://doi.org/10.1017/CBO9780511815805

Statement by H.E. President of the Republic of Botswana Lt.Gen. Seretse Khama Ian Khama on the Current Affairs of the Botswana Democratic Party (2009, August, 26), Tautona Times, no 22 of 2009

Sunday Standard Commentary. (2011 May 15). Where art thou Mr. President? Sunday Standard. Retrieved from www.sundaystandard.info/article.php?

Sunday Standard Reporter. (2009 August 08). Khama Faces Court Action, Sunday Standard. Retrieved from www.sundaystandard.info/article.php?

Taylor, I. (2003). Ditiro tsa Ditlhabololo': Botswana As A Developmental State. PULA: Journal of African Studies, 17(1), 37-50.

Tautuna Times. ( 2009 August 21). Statement By His Excellencythe President Of The Republic Of Botswana Lieutenant General Seretse Khama Ian Khama On The Current Affairs Of The Botswana Democratic Party.

Tsie, B. (1998). The State and Development policy in Botswana. In R.K Hope and Somolekae G. Public Administration and Policy in Botswana, Capetown: Juta \& Co Ltd.

Waldron, J. (1987). Liberal Rights: Collected Papers 1981-1991. Cambridge: Cambridge University Press. 
Weber, M. (1995). The theory of social and economic organisation, edited with an introduction by Talcott Parsons. New York, United States of America: The Free Press.

Zaba, F. (2010 September 12). Zimbabwe Puts Khama 's principles to the test. Sunday Standard Newspaper. Retrieved from www.sundaystandard.info/article.php?

\section{Copyrights}

Copyright for this article is retained by the author(s), with first publication rights granted to the journal.

This is an open-access article distributed under the terms and conditions of the Creative Commons Attribution license (http://creativecommons.org/licenses/by/4.0/). 